UDC 159.923.2:616.89-008.441.3-008.442.6

DOI: $10.26565 / 2410-1249-2020-14-07$

\title{
FEATURES OF NARCISSISTIC REGULATION OF DRUG ABUSE PERSONALITY
}

\author{
@Miliena O. Antonovych \\ candidate for the degree of Doctor of Philosophy 4 years of study \\ Faculty of Psychology, Department of Psychological Counseling and Psychotherapy \\ Kharkiv National University named after VN Karazin \\ Maidan Svobody, 4, 61022, Kharkiv, Ukraine \\ V. N. Karazin Kharkiv National University \\ e-mail: savinamilena@gmail.com; https://orcid.org/0000-0002-2654-1046
}

\begin{abstract}
The article presents the results of a study of the characteristics of narcissistic regulation of drug addicts. The aim of the study is to investigate the features of narcissistic regulation of drug addicts as forms of borderline personality organization and personality types of drug addicts. According to the set goal and objectives of the study, a research sample was formed. Based on informed consent in compliance with the principles of bioethics and deontology during 2019-2020. a psychodiagnostic study of 102 male patients with drug addiction of the opioid group was carried out on the basis of the "Vertical" rehabilitation center at the age of 18-26 years, and 54 healthy males at the age of 18-27 years without signs of somatic, mental pathology and drug addiction. To achieve this goal, we used the following methods: for the study of narcissistic regulation - "Index of the functioning of the Self-system" (Zalutskaya N.M. and oth., 2003); for the study of personality characterological radicals were used test "Self-portrait of personality" Jen M. Oldham and Louis B. Morris. Mathematical processing was carried out using the methods of mathematical statistics (SPSS Statistics 21): methods for checking the reliability of differences in unrelated samples (Mann-Whitney U-test). Conclusions: Narcissistic regulation of drug addicts is based on the formation of an ideal image for others, acting as a social "mask" caused to hide the terrible inner emptiness, baseness and depravity of their own "Self". A rigid internal imperative is based on the background of parent-child relationships and levels the internal infantile dependence on the inflated expectations of parents. The personality profile of drug addicts is based on the multidimensional development of personality types, which introduce individual characteristics into the personality of drug addicts and manifest themselves under certain circumstances, indicating a conditional heterogeneity in these characteristics. The study of the interdependence of personality types with the characterological radicals of narcissistic regulation and drug addicts complements the awareness of the holistic picture of the functioning of an addictive personality. The existing correlations allow drug addicts to form compensatory mechanisms to mask their own narcissistic deficit.
\end{abstract}

Key words: drug addiction, narcissistic regulation, personality types, Self-system.

Topicality. Substance abuse in the modern world is one of the most acute socio-economic, demographic and moral problems, the scale of which determines its attribution to the most important threats to national security [1]. Among the main trends that characterize the drug situation in Ukraine, the greatest concern is the steady rejuvenation of consumers of psychoactive substances. Thus, the main contingent of drug users are young people aged 14 to 30 , ie the intellectual and physical future of our country [1]. Drug addicts have a high comorbidity with various personality disorders [2, 3]. Personality is multifaceted, its structure consists of many components: emotions, volitional qualities, character, skills, abilities and so on [1].

Modern research also shows that drug addicts have impaired psychodynamics, a phenomenon such as "hypersensitivity", which is associated with disorders of narcissistic regulation. [4, 5]. By narcissistic regulation we mean maintaining an emotional balance of feelings of inner stability, selfworth, self-confidence and well-being or self. The psychoanalytic concept of Self reflects the integrity of the individual, its biological and mental unity, in contrast to the "Ego" includes a conscious area and is a regulatory core component of personality [6]. The central problem of narcissism is the theme of its own significance (both underestimated and inflated pole), the value of one's personality. Due to the impossibility of relying on the internal resources of one's own "Self", the narcissistic personality constantly tries only to identify with external objects. Such a violation of the harmonious relationship between internal and external in the structure of 
"Self" is identified with a feeling of emptiness, "grand loneliness". Due to the focus exclusively on the outside world, the narcissistic personality is extremely prone to any, even minor negative or stressful events. Such hypersensitivity creates many difficulties in adaptation. As for drug addicts, these trends lead to periodic disruptions and continued use of psychoactive substances [7-9]. These circumstances significantly update the timeliness and necessity of this study. With this in mind, the purpose of the study was formulated.

The purpose of the study is to investigate the features of narcissistic regulation of drug addicts, as forms of borderline organization of personality and personality types of drug addicts.

Characteristics of the research group. In accordance with the set purpose and objectives of the study, a research sample was formed. On the basis of informed consent in compliance with the principles of bioethics and deontology during 2019-2020, a psychodiagnostic study of 102 male patients with drug addiction of the opioid group was conducted on the basis of the rehabilitation center "Vertical", aged
$18-26$ years, and 54 healthy males, aged $18-27$ years without signs of somatic, mental pathology and drug addiction.

Research methods: to achieve the goal we used the following methods: to diagnose the peculiarities of the organization of narcissistic regulation of personality was used the method "Index of functioning of the Self-system" (Zalutska NM et al., 2003); Jen M. Oldham and Louis B. Morris test was used to study the characterological radicals of personality [10]. Mathematical processing was performed using the methods of mathematical statistics (SPSS Statistics 21): methods to verify the validity of differences in unrelated samples (MannWhitney U-test).

Research results. Assessment of the index of functioning of the Self-system allows to study various aspects of the organization and regulation of the narcissistic system of a drug addict. The results of the study of the organization of the Self-system of drug addicts and the control group are presented in Table 1.

Table 1

Features of narcissistic regulation in the studied groups

\begin{tabular}{|l|l|c|c|c|}
\hline \multicolumn{2}{|c|}{ Indexes } & $\begin{array}{c}\text { Research group } \\
(\mathrm{n}=102)\end{array}$ & $\begin{array}{c}\text { Control group } \\
(\mathrm{n}=54)\end{array}$ & $\begin{array}{c}\text { Significance } \\
\text { of the U-test }\end{array}$ \\
\cline { 3 - 4 } & & Average rank & Average rank & 0.061 \\
\hline 1. & Powerless Self & 74.41 & 60 & 0.587 \\
\hline 2. & Loss of control over emotions and motivations & 71.63 & 67.47 & 0.092 \\
\hline 3. & Derealization / depersonalization & 74.01 & 61.08 & 0.140 \\
\hline 4. & The basic potential of hope & 67.42 & 78.76 & 0.536 \\
\hline 5. & Insignificant Self & 71.79 & 67.03 & $0.008^{*}$ \\
\hline 6. & Negative physical Self & 76.01 & 55.71 & 0.398 \\
\hline 7. & Social avoidance & 72.26 & 65.76 & 0.970 \\
\hline 8. & Archaic escape & 70.42 & 70.71 & 0.315 \\
\hline 9. & Grandiose Self & 68.40 & 76.13 & $0.025^{*}$ \\
\hline 10. & Striving for the perfect Self-object & 65.82 & 83.05 & 0.520 \\
\hline 11. & Thirst for approval & 69.16 & 74.11 & 0.162 \\
\hline 12. & Narcissistic rage & 67.58 & 78.34 & 0.833 \\
\hline 13. & The ideal of self-sufficiency & 70.94 & 69.32 & 0.593 \\
\hline 14. & Depreciation of the object & 69.38 & 73.50 & $0.032^{*}$ \\
\hline 15. & The ideal of values & 66.05 & 82.45 & $0.010^{*}$ \\
\hline 16. & Symbiotic Self Protection & 65.09 & 74.13 & 0.517 \\
\hline 17. & Hypochondriac protection against anxiety & 69.25 & & 0.550 \\
\hline 18. & Narcissistic benefits of the disease & & & \\
\hline
\end{tabular}

Notes: *- ${ }^{*}<0.05$ 
The results of the study show that the following statistically significant indicators were: "negative physical Self", "striving for the perfect Self-object", "the ideal of values" and "symbiotic Self protection".

The indicator "negative physical Self" of drug addicts indicates the presence of a weakened parameter of the Self-system, which determines the extremely painful perception of one's own body, its shortcomings and considers itself defective. There is a high concentration on appearance, constant concentration on the little things of appearance, selfdoubt is formed, the individual is unable to accept their own shortcomings in appearance, even if they do not have them. On the scale of "striving for the perfect Self-object" show that drug addicts suffer from narcissistic pathology. Such individuals rely only on themselves, declare complete independence from others and deny the need for communication and interaction in society. For drug addicts is characterized by a weakening of personality, which begins with uncertainty in their life goals and themselves. The results of the indicator "symbiotic Self protection" signals narcissistic disorders. This is manifested in emotional secrecy when talking to loved ones, an absolute denial of the importance of any relationship. There is a defect of sociability, which is revealed in the denial of the importance of another's opinion and inability to yield even in small things.
Thus, the essence of narcissistic behavior of drug addicts is to form a perfect image of a "shiny facade", due to which drug addicts want to hide the terrible inner emptiness, meanness and depravity of their own "Self". Drug addict's requirements of unlimited perfection to one's own personality are formed, as a rigid internal imperative based on the background of parent-child relations and acting as a rudiment of introjected infantile dependence on inflated expectations of parents. With the fundamental unattainability of the ideal, drug addicts grow up in constant devaluation and self-criticism of their own personality or those of others, which lead to the inability to get any pleasure from life.

To study the characteristics and types of character, we used the method of "Self-portrait of the individual" (D.M. Oldham, Louis B. Morris), which is a combination of stable response strategies and behavior, scenarios for building relationships. Each of the fourteen types has its own distinctive feature, so the combination of their levels of expression in the profile creates a certain characterological portrait of the individual. Significant differences were found using the nonparametric U - Mann-Whitney test in the level of expression of personality types among the studied groups (Table 2).

Table 2

Features of expression of personality types

\begin{tabular}{|l|l|c|c|c|}
\hline \multicolumn{2}{|c|}{ Indexes } & $\begin{array}{c}\text { Research group } \\
(\mathrm{n}=102)\end{array}$ & $\begin{array}{c}\text { Control group } \\
(\mathrm{n}=54)\end{array}$ & \multirow{2}{*}{$\begin{array}{c}\text { Significance of the } \\
\text { U-test }\end{array}$} \\
\cline { 3 - 4 } & Average rank & Average rank & \\
\hline 1. & Conscientious - Obsessively coercive & 69.06 & 57.80 & 0.153 \\
\hline 2. & Self-confident - Narcissism & 60.94 & 85.40 & $0.002^{*}$ \\
\hline 3. & Dramatic - Unnatural acting & 67.76 & 62.20 & 0.482 \\
\hline 4. & Vigilant - Paranoid & 63.23 & 77.63 & 0.068 \\
\hline 5. & Active - Activity on the verge of failure & 66.24 & 67.40 & 0.883 \\
\hline 6. & Devoted - Dependent & 69.78 & 55.33 & 0.067 \\
\hline 7. & Hermit - Schizoid & 66.81 & 65.43 & 0.861 \\
\hline 8. & Empty - Passive-aggressive & 63.90 & 75.33 & 0.144 \\
\hline 9. & Sensitive - Evasion & 63.88 & 75.40 & 0.138 \\
\hline 10. & Ideosyncretic - Schizopathy & 65.11 & 71.23 & 0.439 \\
\hline 11. & Adventurous - Antisocial & 67.66 & 62.57 & 0.520 \\
\hline 12. & Altruistic - Self-destruction & 69.39 & 56.67 & 0.106 \\
\hline 13. & Aggressive - Sadist & 60.62 & 86.50 & $0.001 *$ \\
\hline 14. & Serious - Depressed & 64.53 & 73.20 & 0.271 \\
\hline
\end{tabular}

Notes: ${ }^{*}$ - $\mathrm{p}<0.05$ 
According to the results of the study, we can conclude that the indicators "self-confident narcissism" and "aggressive - sadist" are statistically significant indicators, but these indicators have a higher load for the control group.

Analyzing the results, we can conclude that drug addicts are not characterized by the presence of a dominant personality type, all types contribute their own characteristics to the structure of the individual and manifest themselves under certain circumstances, indicating conditional heterogeneity in these characteristics. Thus, we can conclude that personality type is not a determining factor in the formation and development of maladaptive behavior.

Drug addiction has a multifactorial structure and an essential aspect in the development of drug personality is the presence of certain personality deviations that have formed at the premorbid stage of personality development.

Conclusions. An empirical study of the features of narcissistic regulation and personality types of drug addicts allowed us to draw the following conclusions:

1. Narcissistic regulation of drug addicts is based on the formation of an ideal image for others, which acts as a social "mask" designed to hide the terrible inner emptiness, meanness and depravity of their own "Self". The rigid inner imperative is based on the background of parent-child relationships and reduces the introverted infantile dependence on inflated parental expectations.

2. The personality profile of drug addicts is based on the multifaceted development of personality types that make individual characteristics in the personality of drug addicts and manifest themselves under certain circumstances, which indicates the conditional heterogeneity of these characteristics.

\section{References}

Національний звіт за 2019 рік щуодо наркотичної ситуації (за даними 2018 року) [National report for 2019 on the drug situation (according to 2018)] (2019). https://cmhmda.org.ua/wpcontent/uploads/2020/03/Zvit_s hchodo_narkotychnoi_ta_alkoholnoi_sytuatsii_v_Ukraini _za_2019_rik.pdf.

Kulakov S. A. (2004). Практикум по клинической психологии $u$ nсихотерапии подростков [Workshop on Clinical Psychology and Psychotherapy for Adolescents]. Sankt Petersburg : Rech, pp. 464.
Шабанов, П.Д., Штакельберг О.Ю. (2000). Наркомании: патопсихология, клиника, реабилитация. СПб. Изд-во «Лань», 368.

Змановская, Е.В. (2003). Девиантология: (пособие отклоняющегося поведения). М., 134.

Кохут Х. (2017) Анализ самости. Систематический подход к лечению нарциссических нарушений личности. М. Когито-Центр, 368.

В. Денек., Б. Хильгеншток. (2003). Методика: Тест оценки нарииссизма (адапттация Залуцкой Н.М., Вукс А.Я. под руководством Вида В.Д.) (2003). НИПНИ им. Бехтерева. https://sites.google.com/site/test300m/nrz

Dufner M., Gebauer J.E., Sedikides C., et al. (2019). Selfenhancement and psychological adjustment: A metaanalytic review. Personality and Social Psychology Review. 23(1), 48-72. https://doi.org/10.1177/1088868318756467.

Krizan Z., Herlache A.D. (2018). The narcissism spectrum model: A synthetic view of narcissistic personality. Personality and Social Psychology Review. 22(1), 3-31. https://doi.org/10.1177/1088868316685018.

Miller J.D., Price J., Gentile B., et al. (2012). Grandiose and vulnerable narcissism from the perspective of the interpersonal circumplex. Personality and Individual Differences. 4 507-512. https://doi.org/10.1016/j.paid.2012.04.026.

Щербатых Ю.В. (2008). Русифицированная версия теста Олдхэма-Морриса - эффективный инструмент профессионального отбора и семейного консультирования. Сборник материалов региональной межвузовской конференции ВФ МГЭИ. Воронеж, 41-43.

\section{References}

Наџіональний звіт за 2019 рік щзодо наркотичної ситуачиї (за даними 2018 року) [National report for 2019 on the drug situation (according to 2018)] (2019). https:/cmhmda.org.ua/wpcontent/uploads/2020/03/Zvit_s hchodo_narkotychnoi_ta_alkoholnoi_sytuatsii_v_Ukraini _za_2019_rik.pdf [in Ukrainian].

Kulakov, S.A. (2004). Практикум по клинической психологии u психотерапии подростков [Workshop on clinical psychology and psychotherapy for adolescents]. SPb. Rech` [SPb. Rech], pp. 464. [in Russian].

Shabanov, P.D., Shtakel'berg O.Yu. (2000) Наркомания: патопсихология, клиника, реабилитация [Drug addiction: pathopsychology, clinic, rehabilitation]. SPb. Izd-vo «Lan`» [SPb: Publishing house "Lan"], pp. 368. [in Russian].

Zmanovskaya, E.V. (2003) Девиантология: (пособие отклоняющегося поведения) [Deviantology: (a guide to deviant behavior]. M., pp. 134. [in Russian].

Kokhut Kh. (2017) Анализ самости. Систематический подход $к$ лечению личности нарциссических нарушений. [Analysis of the Self. A systematic approach to the treatment of narcissistic personality disorders]. M.: Kogito-Czentr. [Moscow: Kogito-Center], pp. 368. 
Denek, W., Hilgenstock, В. (2003) Методика: Тест оченки нарииссизма [Methodology: Test for assessing narcissism]. (adapttacziya Zaluczkoj N.M., Vuks A.Ya. под руководством Vida V.D.) [adaptation by Zalutskaya N.M., Vuks A.Ya. under the guidance of Weed V.D.] NIPNI im. Bekhtereva. https://sites.google.com/site/test $300 \mathrm{~m} / \mathrm{nrz}$

Dufner M., Gebauer J.E., Sedikides C., et al. (2019). Selfenhancement and psychological adjustment: A metaanalytic review. Personality and Social Psychology Review. 23(1), 48-72. https://doi.org/10.1177/1088868318756467 [in English].

Krizan Z., Herlache A.D. (2018). The narcissism spectrum model: A synthetic view of narcissistic personality. Personality and Social Psychology Review. 22(1), 3-31. https://doi.org/10.1177/1088868316685018.
Miller J.D., Price J., Gentile B., et al. (2012). Grandiose and vulnerable narcissism from the perspective of the interpersonal circumplex. Personality and Individual Differences. $\quad 4 . \quad 507-512$. https://doi.org/10.1016/j.paid.2012.04.026.

Shherbaty`kh Yu.V. (2008). Русифициированная версия теста Олдхама-Морриса - эффективный инструмент профессионального отбора и семейного консультирования. [The Russian version of the OldhamMorris test is an effective tool for professional selection and family counseling]. Сборник материалов региональной межвузовской конференции ВФ МГЭИ. [Collection of materials of the regional interuniversity conference of the WF IGE]. Voronezh, pp. 41-43.

\section{ОСОБЛИВОСТІ НАРЦИСИЧНОЇ РЕГУЛЯЦЇ̈ НАРКОЗАЛЕЖНИХ} Антонович Мілена Олександрівна

здобувач ступеня доктора філософії 4 року навчання факультету психології кафедри психологічного консультування і психотерапії Харківського національного університету імені В. Н. Каразіна майдан Свободи, 4, 61022, м. Харків, Україна У статті представлені результати дослідження особливості нарцисичної регуляції наркозалежних. Мета дослідження - дослідити особливості нарцисичної регуляції наркозалежних, як форми пограничної організації особистості та типи особистості наркозалежних. Характеристика дослідницької вибірки: на основі інформованої згоди 3 дотриманням принципів біоетики і деонтології протягом 2019-2020 рр. було проведено психодіагностичне дослідження 102 хворих чоловічої статі з наркотичною залежністю опіоїдної групи на базі реабілітаційного центру «Вертикаль», віком 18-26 років, та 54 здорових особи чоловічої статі, віком 18-27 років без ознак соматичної, психічної патології та наркотичної залежності. Для реалізації мети нами були використані наступні методи: для діагностики особливостей організації нарцисичної регуляції особистості був використаний метод «Індекс функціонування Self-системи» (Залуцька Н. М. зі співавт., 2003); для дослідження характерологічних радикалів особистості був використаний тест «Автопортрет особистості» Джен М. Олдхем й Луі Б. Морріс. Математична обробка проводилася за допомогою методів математичної статистики (SPSS Statistics 21): методи перевірки достовірності відмінностей незв'язаних вибірок (U-критерій Манна-Уїтні). Висновки: нарцисична регуляція наркозалежних базується на формуванні ідеального образу для оточуючих, який виступає соціальною «маскою», що викликана приховати жахливу внутрішню порожнечу, ницість і порочність власного «Я». Жорсткий внутрішній імператив базується на тлі батьківсько-дитячих стосунках та редикує інтроековану інфантильну залежність від завищених очікувань батьків. Профіль особистості наркозалежних базується на багатоаспектній розвиненості типів особистості, які вносять індивідуальні характеристики в особистість наркозалежних та проявляють себе при певних обставинах, що свідчить про умовну гетерогенність за даними характеристиками. Вивчення взаємозалежностей типів особистості з характерологічними радикалами нарцисичної регуляціії наркозалежних доповнює усвідомлення цілісної картини функціонування адиктивної особистості. Наявні кореляційні зв'язки дозволяють наркозалежним сформувати компенсаторні механізми для маскування власного нарцисичного дефіциту.

Ключові слова: наркозалежність, нарцисична регуляція, типи особистості, Self-система 